\title{
Diagnosis and management of vaginal dryness in menopause
}

\author{
Ali Baziad \\ Department of Obstetrics and Gynecology \\ Faculty of Medicine, Universitas Indonesia, Dr. Cipto Mangunkusumo Hospital, Jakarta, Indonesia
}

\section{ABSTRAK}

Tujuan: Menelaah diagnosis dan penanganan ke keringan pada vagina pada perempuan menopaue

Metode: Kajian pustaka

Hasil: Kekurangan estrogen berdampak negatif terhadap vagina dan saluran kemih. Vagina menjadi kering (atrofi) sehingga merasa sakit ketika melakukan hubungan seks. Diagnosis atrofi vagina berupa keluhan vagina kering $(75 \%)$, nyeri sanggama (38\%), gatal dan keputihan. Tidak jarang pasien mengeluh nyeri berkemih, sering kencing malam hari, inkontinensia dan infeksi saluran kemih berulang. Mukosa servik, vagina dan vulva tipis. Vagina mudah berdarah. Diagnosis dapat juga ditegakkan dengan mengukur $\mathrm{pH}$ vagina dengan menggunakan kertas likmus dan sitologi vagina. Penanganannya adalah dengan pemberian estrogen lokal jenis estrogen lemah (E3) berupa krim. Pemberian E3 krim tidak perlu dikombinasikan dengan progestogen. Jenis TH lokal yang lain adalal DHEA krim. Pemberian estrogen kuat (E2) atau equin estrogen harus selalu dikombinasikan dengan progestogen untuk mencegah hiperplasia endometruim, baik diberikan secara lokal maupun secara sistemik. E3 krim juga aman diberikan pada perempuan dengan kanker payudara jang mengalami atrofi vagina

Simpulan: Kekurangan estrogen menyebabkan atrofi vagina dengan keluhan vagina kering.Atrofi vagina juga menyebabkan gangguan berkemih . Diagnosis berdasarkan gejala, pemeriksaan $\mathrm{pH}$ vagina dan sitologi vagina. Penanganan nya adalah dengan pemberian TH dengan estrogen. E3 krim paling efektif menghilangkan keluhan yang diakibatkan oleh vagina kering dan keluhan yang diakibatkan oleh kandung kemih.

Kata kunci: vagina kering, diagnosis, penanganan, menopaue, terapi hormon $(\mathrm{TH})$

\begin{abstract}
Objective: To review the diagnosis and management of vaginal dryness in menopausal women Methods: Literature review

Results: Lack of estrogen negatively impacts the vagina and the urinary tract. The vagina becomes dry (atrophic) and then causing pain during sexual intercourse. Vaginal atrophy can be diagnosed in the form of vaginal dryness $(75 \%)$, painful sexual intercourse (38\%), itching and discharge complaints. Sometimes the patient complained pain in urinating, frequent night urination, incontinence and recurrent urinary tract infections. Mucose of the cervix, vagina and vulva are thin. Vagina can bleed easily. Diagnosis can also be made by measuring the $\mathrm{pH}$ of the vagina by using litmus paper and vaginal cytology. The management involves administration of local estrogen treatment using weak estrogen (E3) in the form of a cream. E3 cream does not need to be combined with progestogen. Other type of local hormonal therapy (TH) is DHEA cream. Giving a strong estrogen (E2) or equin estrogen should always be combined with progestogen to prevent endometrium hyperplasia, either administered locally or systemically. E3 cream is also safe in women with breast cancer who experienced vaginal atrophy.

Conclusion: Lack of estrogen causes vaginal atrophy with symptoms of vaginal dryness. Vaginal atrophy also causes urinary problems. Diagnosis is based on symptoms, examination of vaginal $\mathrm{pH}$ and vaginal cytology. The management is by administering HT with estrogen. E3 creams is the most effective in relieving complaints caused by vaginal dryness and complaints caused by the bladder.
\end{abstract}

Keywords: vaginal dryness, diagnosis, management, menopause, hormonal therapy (HT)

Correspondence: Ali Baziad, Department of Obsteetrics and Gynecology, Faculty of Medicine, Universitas Indonesia, Dr. Cipto Mangunkusumo Hospital, Jakarta, Indonesia email: alibaziad@gmail.com; endorep@cbn.net.id

\section{INTRODUCTION}

Female genitalia and urinary tract's embryology are associated due to the same origin. The two organs need estrogen. Vaginal dryness is inseparable with vaginal atrophy. Other terms for vaginal atrophy are vulvovaginalatrophy or urogenital atrophy. In reproductive age the estrogen level is sufficient, the vaginal wall is thick, elastic, the vaginal rugae are intact, blood flow to vagina is increasing, vaginal lubrication is good and acidic vaginal $\mathrm{pH}(\mathrm{pH}<5)$. Vaginal atrophy is estimated to occur in $10-40 \%$ of women, mostly caused by estrogen deficiency. It is commonly found at menopausal age and the elderly, but may also occur at a young age due to premature menopause. Premature menopause can occur due to the removal of the two ovaries, hipotamic amenorrhea, hyperprolactinemia, lactation, the use of antiestrogen drugs, anticancer drugs and radiation $^{1}$

\section{DIAGNOSIS}

Menopause and from symptoms caused by vaginal atrophy such as vaginal dryness (75\%), painful sexual intercourse (38\%), vaginal itching and discharge ${ }^{2}$. Because internal genital and urinary tract are originated from the same source in embryology, the patient also complained of painful urination, frequent night urination, incontinence and recurrent urinary tract infection ${ }^{3}$. 


\section{PHYSICAL EXAMINATION}

In internal examination of vaginal wall the mucous of the cervix, vagina and vulva epithelium are thin and the lower portio bleed easily. There is no vaginal rugae, the vaginal opening retracts, vagina looks pale and sometimes there are visible petechial or signs of inflammation. Because of the acidic vaginal $\mathrm{pH}$ (3.5-5.0) fell into alkaline $\mathrm{pH}$ (6.0 to 8.0), pathogens including fungi and bacteria (coli) are easily found, causing vaginal odor $^{3}$. Spontaneous or postcoital micro/ macroulceration can also be found. In speculum examination, the vagina bleed easily and very painful for the patients. In women who are not sexually active or rarely do sexual intercourse, vaginal atrophy can lead to vaginal narrowing and shortening ${ }^{4}$.

Objectively, there are two ways of examination for the diagnosis and evaluation of treatment, it is by measuring vaginal $\mathrm{pH}$ by using litmus paper and the vaginal maturation index (\% superficial cells are low compared with intermediate cells and parabasal cells)

\section{MANAGEMENT OF VAGINAL ATROPHY}

The symptoms caused by vaginal atrophy should not be underestimated, especially the impact on the sexual quality $^{5} .50-70 \%$ of women with vaginal atrophy symptoms do not seek doctor's help to get treatment, because they thought that the complaint is a natural process and sexual intercourse is not necessary anymore ${ }^{6,7}$. Most of women are shy to be caught by doctor if they had not had sex for a long time. Instead of a doctor, the women tried to deal with it in her own way, which is not having sex anymore. What about the husband who did not experience andropause, is the husband ready to abstain from intercourse for years? Not the wife but the husband who frequently visit the doctor to want to know why his wife does not want to have sex again.

Vaginal atrophy and urinary symptoms are mostly caused by estrogen deficiency, therefore the rational treatment is estrogen administration. Estrogen preparations can be administered in systemic or local. The most effective and safe treatment is a local vaginal estrogen because it does not have a systemic impact. Local estrogen can be administered in the form of tablets/ suppositories, creams, or vaginal rings. Local estrogen might contain strong estrogen such as estradiol (E2) and estrogen equin conjugate, and contain a weak estrogen such as estriol (E3) and estrone (E4). The use of strong estrogen can trigger the growth of endometrium leading to endometrial hyperplasia and endometrial cancer in the future ${ }^{8}$. Therefore any strong estrogen adminis- tration should always be combined with progestogen. Endometrial hyperplasia or cancer were not found in short-term use for 1-2 years with a low dose $(25 \mathrm{ug})^{9}$. In the instructions issued by the International Menopause Society and The North American Menopause Society, the use of low dose estrogen locally does not need additional progestogen ${ }^{10,11}$.

Of all types of local estrogen, estriol cream is the most widely used. It works very effectively to eliminate complaints caused by vaginal atrophy or complaints caused by urinary tract despite of its weak nature. Weak estrogen has no systemic effect at all so it does not need to be combined with progestogen. It does not cause a venous thromboembolism and may even be given to women with breast cancer ${ }^{12,13}$.

Not only estrogen receptors, but vulva and vagina also have androgen receptors, therefore androgen might be administered for women with vaginal atrophy. Combination of estrogen with testosterone cream increase sexual desire of women, so that women have the desire for sex, but unfortunately testosterone has systemic effects. Free testosterone levels in the blood reaches $54 \%{ }^{14}$. Research is still continue to see the effect of the vaginal ring containing E2 and testosterone cream $1 \%$ in women with breast cancer who experience vaginal atrophy. Giving DHEA (dehydroepiandrosterone) is very effective in relieving local complaints caused by vaginal atrophy, and the results was already visible within two weeks ${ }^{15}$. In order to get a good resorption, the cream is placed near the cervix or posterior fornix. The lowest resorption is when it is placed in the distal vagina.

Giving oral tablet estrogen or estrogen + progestogen also can eliminate the complaints of vaginal atrophy. However, oral administration is still debatable, especially against the risk of breast cancer. Research by Women's Health Initiative (WHI) reported that estrogen combined with progestogen increased the incidence of breast cancer, but estrogen alone in women without uterus decreased breast cancer incidence ${ }^{16,17}$. Keep in mind that the WHI study is heavily criticized, many errors were found in its methodology. Oral administration cannot eliminate complaints quickly compared to the local administration.

In September and October 2014 results of a research said that in postmenopausal women treated with HT for 10 years there was no breast cancer found ${ }^{18}$. There was also no breast cancer found in transdermal administration of low dose HT, either the combination or not $^{19,20}$. The incidence of breast cancer is not much 
different among women using HT with women who gain weight $5 \mathrm{~kg}$, or women who consume alcoholic drinks two glasses per day ${ }^{21-23}$.

\section{OLD MANAGEMENT}

Repair of vaginal cytology and blood flow to the atrophic vaginal wall usually only can be seen after several weeks of treatment. The maximum results obtained after several months of treatment. Vaginal pain disappeared after 6-12 months of treatment ${ }^{24}$. In the long-term use (years) a lower dose is always used. Sometimes after the treatment is stopped, the complaints arise. Women discontinued treatment because existing drugs available are only for 3-6 months, and women follow that advice.

The benefits of estrogen against urine incontinence are still debatable among experts. Until now, the benefits of estrogen can only be seen in women with stress incontinence. Improvement of urethral pressure profile in women with stress incontinence is already visible after four - six weeks of estrogen administration, however, to get the better results the long term use is recommended ${ }^{2}$. Estrogen administration also decrease the incidence of urogenital infections and episodes incontinence in elder women. It improves the vaginal flora and relieves vaginal mucosal atrophy ${ }^{25}$.

\section{LOCAL ESTROGEN'S SIDE EFFECT}

Side effects on the administration of estriol cream is almost never found. However creams containing estradiol or conjugate equin estrogen sometimes cause irritation of the vagina, vaginal discharge, bleeding, pelvic pain, breast tenderness and neuropathy. Studies have proven that there is no thromboembolic event or increase the incidence of metastasis in women with breast cancer treated with local estrogen. Note that when a severe vaginal atrophy are not treated, then there will be complications such as recurrent cystitis until pyelonephritis. 30-100\% of women with breast cancer or gynecologic cancer experienced sexual dysfunction ${ }^{26}$. In women with cervical cancer, ovarian cancer or endometrium cancer who are undergoing chemotherapy or radiation and complain vaginal atrophy, may HT be given? For breast cancer all experts agree that local estrogen should be the treatment, but for gynecologic cancer there is still no agreement. The efficacy and safety of Complementary Alternative Medicine (CAM) for women with complaints caused by vaginal atrophy are still cannot be proven ${ }^{27}$.
Archeologist is the best husband a woman can have, the older she gets, the more he is interested in her Agatha Christie (1890-1976)

\section{REFERENCES}

1. Goldstein AR. When sex hurts. Evaluation and management of dyspareunia? Abstract Book of 20th Anual Meeting of North American Menopause Society. San Diego CA; 2009. p. 27.

2. Kenemanss P, Barenstein R, van der Weijer P. Practical HRT. Int Med Forum. 1966:19-27

3. Caillowvette JC, scrap CF Jr, Zimmerman GJ, et al. Vaginal $\mathrm{pH}$ as a marker for bacterial pathogens and menopausal status. Am J Obstet Gynecol. 1977;176:1270-5.

4. Robinson D, Cardozo I. The menopause and HRT. Urogenital effect of hormonal therapy. Best Pract Res Clin Endocrinol Metab. 2003;17:91-104.

5. Graziottin A, Leiblin S. Biological and physiological pathophysiologi of female sexual dysfunction during the menopause transition. J Sex Med. 2005;2:133-45.

6. Nappi RE, Kokotkierepin M. Women, s voices in the menopause.results from an international survey on vaginal atrophy. Maturitas. 2010:67.

7. Calleya-J Agius, Brincart M. Urogenital atrophy. Climactric. 2009; 12:279-85.

8. Suckling J, Kennedy R., Letharby A, et al. Local estrogen therapy for vaginal atrophy in postmenopausal women. Cochrane Database Syst Rev. 2006;4.

9. Bracmann G, Bouchart C, D Hoppe et al. Efficacy and safety of low-dose regiment of conjugated estrogen cream administered vaginally. Menopause. 2009;16:719-27.

10. Pines A, Sturdee DW, Birkhamer WH et al. Updated Recommendations of postmenopausal hormone therapy. Climacteric. 2007;10:181-94.

11. North American Menopause Society. Estrogen and progestogen use in postmenopausal women: 2009 Statement of the North American Menopause Society. Menopause 2010;17:242-55.

12. Lammerink EA, de Boek GH, Schroder $\mathrm{CP}$, Mourits MJ. The management of menopausal symptoms in breas cancer survivors: case-based approach. Maturitas. 2012;73:265-8.

13. Cody JD, Jacobs Court, Richardson J, et al. Oestrogen therapy for urinary incontinence in postmenopausal women. Cochrane Database Syst Rev. 2012;10. 
14. Rougnnanden C, Agraul S, P Dubey, Choudhury M, Jain A. A comparative study of the effects of local estrogen with or without local vulvovaginal and testosterone on sexual dysfunction in postmenopausal women. J Sex Med. 2010;7:128490.

15. Lobrie F MD, David Archer MD, Celine B MD, Fortier M, MD, MD Cusan L, Gomez JL MD, Girard G MD et al. Intravaginal dydroepiandrosterone (Prasteron), a physiological and highly efficient treatment of vaginal atrophy. Menopause. 2009;16:907-22.

16. Writing Group for the Women, s Initiative Investigators. Risk and Benefits of estrogen plus progestin in healthy postmenopausal women. Principal results from the women health initiative randomized control trial. JAMA. 2002;288:321-33.

17. The women's health initiative steering committee. Equinine Effect of conjugated estrogen in postmenopausal women. Health initiative randomized controlled trial. JAMA. 2004;291: 1701-2.

18. Hormone therapy have many favorable effects in newly menopausal. Initial findings of the Kronos Early Estrogen Prevention Study (keeps). NAMS press release. 2012;3.

19. Opatiny L, Dell Aniellos, Assouline S, Suissa S. Hormone replacement therapy use a variation in the risk of breast cancer. BJOG. 2008;115:169-71.
20. Chelebowski RT, Manson JE, Anderson GL. Estrogen plus progestin and breast cancer incidence and mortality in the WHI observational study. J Natl Cancer. 2013;17:256-35.

21. Chen WJ. Postmenopausal hormone therapy and breast cancer risk: current status and unanswered questions. Endocrinol Metab Clin North AM. 2011;40:509-18.

22. Kroenke $\mathrm{CH}$, Chen WJ, Rosner B, Holmes MD. Weight gain, and survival after breast cancer diagnosis. J Clin Oncol. 2005;23:1370-8.

23. Anandov A, Hainant P, Romieu I. Role of obesity in the risk of breast cancer: lessons from anthropometry. J Oncol. 2013;90:64-95.

24. Mettler L, Olsen PG. Long term treatment of atrophic vaginitis with low dose oestradiol vaginal tablets. Maturitas. 1991;13:23-31.

25. Raz R, Stamm WE. A controlled trial of intravaginal estriol in postmenopausal women with recurrent urinary track infeksion. New Engl J Med. 1993;329:753-6.

26. Krychman ML, Pereira L, Carter J, Amsterdam A. Sexual oncology: Sexual health issues in women with cancer. Oncology. 2006;71:18-25.

27. Castelo BC, Cancelo M, Villero J, et al. Management of postmenopausal vaginal atrophy and atrophic vaginitis. Maturitas. 2005;52:46-52. 